DOI: https://doi.org/10.34069/AI/2021.47.11.1

How to Cite:

Batukova, L., Bagdasaryan, N., \& Bagdasaryan, L. (2021). A conceptual model of a transition from technogenic to human-induced globalization. Amazonia Investiga, 10(47), 9-18. https://doi.org/10.34069/AI/2021.47.11.1

\title{
A conceptual model of a transition from technogenic to human-induced globalization
}

\section{Концептуальная модель перехода от техногенной к человекогенной глобализации}

Received: September 15, 2021

\begin{abstract}
Globalization is a fundamental integrative social mechanism, in which two stages can be distinguished: "technogenic globalization" and "human-induced globalization". The result of a phase transition from the first stage to the second should be the final formation of an information society. The aim of the study was the theoretical substantiation of globalization as a mechanism for a transition to an information society, and identification of the role and place of technogenesis in it. The paper considers the essence of a transition to an information society in the context of the replacement of technogenic globalization with human-induced globalization, and draws a conclusion about the place of technogenesis and artificial intelligence, as its institution, in human-induced globalization. It is shown that at the present stage, human-induced globalization should be implemented with a focus on the following directions of technogenesis: a) formation of breakthrough directions of development of the "Human Variable of society"; b) ensuring the demand for innovative development; c) acquisition by society of a new development resource "human-energy-informational plasma"; d) formation of a new "capital" mechanism - the mechanism of self-growth of the value of social life on the basis of the investment flow of humanenergy-informational plasma.
\end{abstract}

Accepted: October 20, 2021

\author{
Written by: \\ Louise Batukova ${ }^{1}$ \\ https://orcid.org/0000-0003-2978-6396 \\ Naira Bagdasaryan ${ }^{2}$ \\ https://orcid.org/0000-0003-4433-6852 \\ Lusine Bagdasaryan ${ }^{3}$ \\ https://orcid.org/0000-0002-4722-9238
}

\begin{abstract}
Аннотация
Глобализация - это фундаментальный интегративный общественный механизм, в котором можно выделить две стадии: «техногенная глобализация» и «человекогенная глобализация». Результатом фазового перехода от первой стадии ко второй должно стать окончательное формирование информационного общества. Целью исследования явилось теоретическое обоснование глобализации, как механизма перехода к информационному обществу, определение роли и места техногенезиса в нем. В работе рассмотрена сущность перехода к информационному обществу в контексте смены техногенной глобализации человекогенной глобализацией, сделан вывод о месте техногенезиса и искусственного интеллекта, как его института, в человекогенной глобализации. Показано, что на современном этапе должна быть реализована человекогенная глобализация с фокусом на следующие направления техногенезиса: а) формирование прорывных направлений развития “Человеческой переменной общества"; б) обеспечение спроса на инновационное развитие; в) обретение обществом нового ресурса развития - - «человеко-энергоинформационной плазмы»; г) формирование нового «капитального» механизма механизма самовозрастания ценности общественного бытия на основе
\end{abstract}

\footnotetext{
${ }^{1}$ Doctor of Economics, Associate Professor, Siberian Federal University, Russia.

${ }^{2}$ Assistant, Siberian Federal University, Russia.

${ }^{3}$ Assistant, Siberian Federal University, Russia.
} 
Keywords: globalization, technogenic globalization, human-induced globalization, innovative development, technogenesis.

\section{Introduction}

In this paper, globalization is considered as an integrative social mechanism for ensuring a transition of society to the information type. The most important element of globalization is the mechanism of technogenesis (Kamann \& Nijkamp, 1991). At the same time, artificial intelligence is one of the key institutions of technogenesis (Zhang \& Lu, 2021). The need for such a consideration is determined by the fact that only an understanding of the fundamental essence of the mechanism of a transition to an information society can serve as a theoretically significant basis for identifying the role and place of artificial intelligence (for example, Kumar \& Kalse, 2021; Xu \& Babaian, 2021; Verma et al, 2021).

The studies conducted allow concluding that, by the essence and direction of integrative processes in society, globalization goes through two stages of maturity - the stage of "technogenic globalization" and the stage of "human-induced globalization" (Batukova et al, 2019a; Batukova et al, 2019b). The stage of technogenic globalization carries out systematic preparation of localized societies (peoples of countries, regions), which have approached the limit of their industrial development, for transformations that will ensure their transition to an information society (Tsuji, 2019). The stage of humaninduced globalization is the next stage, which implies the formation of the key foundations of an information society, a stable approach to new factors of social development (including economic growth). Both stages of globalization include the mechanism of technogenesis as the key mechanism. A transition from one stage to another mediates a phase transition, which means a qualitative transformation of the structureforming social relations, and hence the organizational structures and institutions of society. The conducted theoretical studies allow concluding the following (Batukova et al, 2019a; Batukova et al, 2019b):

a) formation of a new mechanism for creating capital - a mechanism for self-growth of the value of social life based on the investment инвестиционного потока человеко-энергоинформационной плазмы.

Ключевые слова: глобализация, техногенная глобализация, человекогенная глобализация, инновационное развитие, техногенезис.

flow of "human-energy-informational plasma" (HEIP);

b) the emergence of a new resource of social development - the flow of creative selfrealization of the Human Variable of society (HV of society).

These factors should be considered as the most important areas that should determine the development priorities and tasks of technogenesis and artificial intelligence in an information society.

The aim of the study is to theoretically substantiate globalization as a mechanism for a transition to an information society, to identify the role and place of technogenesis in it. The paper considers the essence of a transition to an information society in the context of the replacement of technogenic globalization with human-induced globalization, and draws a conclusion on the place of technogenesis and artificial intelligence, as its institution, in humaninduced globalization.

\section{Theoretical Framework}

The studies by many researchers analyze the transformations of social organization that take place during a transition from an industrial to a post-industrial society. During the initial discussions, the options for the name of an expected postindustrial society varied. Now, in terms of the frequency of mention, one can say that the name "information society" has been established for a post-industrial society. In this regard, all research related to a post-industrial society, is referred to the research of an information society. The concept of an information society began to form in the Western academic community (for example, Tsoukas, 1997; Keskinen, 2001; Ahlqvist, 2005; Banuls \& Salmeron, 2007; O'Neill, 2012). Initially, this concept was intended to focus the attention of society on the changes that accelerated progress in the field of informatization of social relations makes to the existing social way of life. In this regard, it should be said that the traditional understanding of an information society implies 


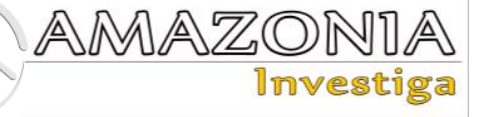

a large-scale digitalization of the sphere of public and, above all, economic relations. In the traditional sense, a deeply and widely digitalized economy is seen as the core of an information society, communicating the digitalization of public relations in all other spheres of life (Martin, 1997). Within the framework of this consideration, technogenesis in general, and artificial intelligence in particular, appear as an organizational attractor promoting the digitization of social relations. This promotes the mechanism of technogenesis to the position of the organizational leader of a transition to an information society, but at the same time forms the right basis for the technosphere to take the leadership in an information society (Drotianko \& Yahodzinskyi, 2019). If this is possible, it will mean a defeat in the rights of HV of society. This, in turn, makes it possible for the technosphere, represented by the institution of artificial intelligence, to dictate the conditions and place restrictions on the participation of $\mathrm{HV}$ of society in the processes of globalization. That is, in the implementation of this scenario, $\mathrm{HV}$ of society is ranked second in an information society. This, of course, forms existential challenges for the evolution of human civilization as a whole (Nusratullin et al, 2020).

\section{Methodology}

Within the framework of this study, a model has been proposed for considering globalization as a fundamental integrative social mechanism that goes through qualitatively different stages of development. This enables to see that the formation of the organizational foundations of an information society should be based on humangenerated globalization, the leader and driving force of which is $\mathrm{HV}$ of society. Within the framework of human-generated globalization, the institutions of technogenesis, and, accordingly, of artificial intelligence, have specific tasks to support the leader of an information society - HV of society. Quite specific restrictions correspond to such tasks. This forms the basis of legal certainty for the inclusion of technogenesis and artificial intelligence in social relations.

To reveal the essence of the proposed conceptual model of a transition from technogenic to humaninduced globalization, the following issues have been consistently addressed in this paper:

1. Identification of the key resourcemotivational factors of technogenesis that determine economic growth in the context of technogenic globalization.
2. Identification of the focus of the evolution of public relations in technogenic globalization.

3. Development of a model of a phase transition from technogenic globalization to human-made globalization.

4. Development of a scheme of corridors for the development of HV of society and the technosphere at the stage of technogenic globalization.

5. Development of a structural and logical scheme for substantiating the limit of achieving technogenic globalization in the period of high maturity.

\section{Results and Discussion}

As noted above, the traditional understanding of an information society is largely technocratic, implying, as a dominant of social development:

a) economic growth, which is equal to social development;

b) leadership positions of the genetic development of engineering and technology - that is, the leadership of the mechanism of technogenesis, not only in the formation of the technosphere, but also in the formation of social relations.

It follows from the identified dominant that a transition to an information society is determined by the leadership positions of the technosphere, the key mechanism of which appears to be technogenesis. This is illustrated as follows. Everything starts with the development of individual processes of technogenic development required to support various spheres of society. At a certain stage of maturity, technogenic processes merge into a single, mutually supportive, stable stream of relations regarding the reproduction and innovative renewal of technogenic development processes. A single network of stable, reproducible relations of the innovative development of the technosphere is formed as the mechanism of technogenesis. Due to the everincreasing opportunities and the need for financing, technogenesis seeks to involve all areas of human activity in its sphere of influence and spread on the ever-increasing territorial scale, that is, to globalize. Globalization turns technogenesis into a force that, on a technogenic basis, integrates human society. This reasoning allows concluding the essence of the mechanism of technogenesis as an element of technogenic globalization. Technogenesis, as an element of technogenic globalization, is a network set of stable relations about coordinated transformations of the system-forming spheres of 
society (socio-economic, institutional, governmental, etc.) based on the introduction of innovative scientific, technical and technological engineering solutions. The latter are replaced on the basis of technogenetic continuity, which includes evolutionary changes and periodic revolutionary leaps. Thus, by technogenic globalization the author means the integration of society based on the leadership of technogenesis. From the standpoint of the systemic paradigm, technogenic globalization is a dynamic system formed by the interaction of the following system-forming elements:

a) the technosphere developing under the influence of technogenesis; b) institutional and organizational structuring and functional organization of society, constituted by the state of the technosphere during the period of technogenic globalization;

c) $\mathrm{HV}$ of society, identified by a) and b).

The elements are ranked according to the degree of decrease in the leadership, respectively, the technosphere being the leader, and HV of society being the follower in the given set of elements. The stage of technogenic globalization provides the preparation of an industrial society for the transition to an information society, through the formation of the following key resourcemotivational factors (KRMF) (Table 1).

Table 1.

Key resource-motivational factors of technogenesis that determine economic growth in the context of technogenic globalization.

\begin{tabular}{|c|c|}
\hline KRMF & Description \\
\hline $\begin{array}{l}\text { KRMF } 1- \\
\text { investment in } \\
\text { innovative } \\
\text { development of } \\
\text { the technosphere }\end{array}$ & $\begin{array}{l}\text { 1) investments in breakthrough engineering and technology innovations, which } \\
\text { literally explode individual functional areas of the technosphere and clear a place } \\
\text { for their fundamental transformation; } \\
\text { 2) investments in the adaptive innovative development of scientific, technological } \\
\text { and industrial development areas associated with leadership by absorbing } \\
\text { innovations from the leading areas. }\end{array}$ \\
\hline $\begin{array}{l}\text { KRMF } 2- \\
\text { formation of } \\
\text { mass demand for } \\
\text { innovative } \\
\text { products }\end{array}$ & $\begin{array}{l}\text { 1) bringing to the uniformity of the way of life, socio-cultural forms, institutional } \\
\text { structure, and, accordingly, consumer behavior of the widest possible masses of } \\
\text { the people around the world; } \\
\text { 2) the impact on the psychology of the masses, on the national and business culture } \\
\text { of peoples and states in order to form big predictable trends in the field of } \\
\text { consumption, for example: } \\
\text { (a) the formation of a fashion for any material goods or public fears regarding the } \\
\text { occurrence of an event, which requires additional consumption; } \\
\text { (b) the formation of waves of consumer hype; } \\
\text { (c) the instilling a consumer psychology that links the feeling of happiness with the } \\
\text { fact of owning something; } \\
\text { (d) the formation of an inclination towards collecting and accumulating innovative } \\
\text { and/or prestigious products, etc. }\end{array}$ \\
\hline
\end{tabular}

Source: developed by the author

The factors listed in Table 1 form a number of accents in the evolution of social relations (Figure 1). In turn, these accents lead to the accumulation of institutional, resource and structural-functional tensions in the period of high maturity of technogenic globalization (Figure 2, part B). The selected tensions include:

1. Reflection of any system to partner interaction is the basis of its selfidentification and a factor that determines the vector of the system development. But technogenic globalization destroys the parity economic, scientific/technological partnership between local societies. Therefore, degradation processes in some states or countries of the human civilization, initiated by technogenic globalization, destroy the mechanisms of constructive reflection of all, and, accordingly, the mechanisms of self-regulation of civilizational development as a whole.

2. Under technogenic globalization, the share of chaotic social systems - those with a reduced capacity for self-government increases. This is a factor of the following:

a) reducing the possibility of constructive reflection at the interstate level as a whole;

b) increasing the burden on management systems in more successful countries and regions resulting in a massive decline in the 


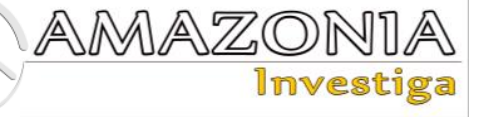

quality of management decisions taken at all levels;

c) forming imbalances in management systems on a global scale.

3. Taken together, the processes listed in clauses 1 and 2 lead to a whole range of specific transformations in the information support system of society, which reduce the availability of high-quality information resources, and therefore the true state of development of society, its technosphere, the mechanism of technogenesis is no longer recognized even at the highest levels of society.

4. Clause 3 leads to a total decrease in motivation for balanced innovative development at the global level. This leads to breakthrough innovative development of some areas of science and technology and others lagging behind. But the consequence of this process is a low return on even "broken through" areas. And in many cases, a "financial and innovative dead end" simply occurs - even at a potential level, it is impossible to pay off certain scientific and technological areas. Everything, on the whole, reduces the rates of innovative transformations and creates conditions for a slide towards "a stagnation of technogenesis".

5. The internal logic of technogenic globalization is pushing for the emergence of new forms of totalitarianism - a digital totalitarianism in the interests of protecting the competitive position of the former economic, scientific and technological leaders. Moreover, in this case, a digital totalitarianism is not so much a system of rigidly administered social relations, but rather a system of limiting their development in principle, including through the media and other mechanisms. In general, this contributes to the formation of the effect of "a stagnation of technogenesis".

\section{Accents in the evolution of public relations during technogenic globalization caused by key}

resource-motivational factors (KRMF)

\begin{tabular}{|c|c|}
\hline $\begin{array}{l}\text { KRMF 1: investing in the development of the } \\
\text { technosphere }\end{array}$ & $\begin{array}{c}\text { KRMF 2: Formation of mass demand for } \\
\text { innovative products }\end{array}$ \\
\hline $\begin{array}{c}\text { Problems of KRMF 1: } \\
\text { - investments inter se are not sufficiently } \\
\text { coordinated, often being of an eclectic nature; } \\
\text { - innovations do not create enough synergistic } \\
\text { effects in the development of society, high risks, } \\
\text { not always enough payback }\end{array}$ & $\begin{array}{l}\text { Problems of KRMF 2: } \\
\text { - highly innovative products require the formation } \\
\text { of new sales markets, which is always associated } \\
\text { with complexity and high cost; } \\
\text { - products with a small degree of innovation often } \\
\text { have problems with promotion and payback. }\end{array}$ \\
\hline $\begin{array}{l}\text { The main accents in the evolution of public } \\
\text { relations mean the aspiration of the leading } \\
\text { economic territories to the artificial: } \\
\text { - consolidation of technogenic dominance in } \\
\text { specific areas of the technosphere through } \\
\text { inhibition of changes of the leading directions in } \\
\text { ttechnogenesis. Along the chain, this slows down } \\
\text { the development of society as a whole, but it } \\
\text { creates conditions for the emergence of innovative } \\
\text { mechanisms of geoeconomic and geopolitical } \\
\text { pressure on real and potential competitors, } \\
\text { - extending the life cycle of obsolete technologies } \\
\text { by organizing their marketing sales to the } \\
\text { periphery of economic development. This creates } \\
\text { an opportunity to maintain a financial flow from } \\
\text { obsolete elements of the technosphere, which } \\
\text { reduces the motivation to invest in innovative } \\
\text { development. }\end{array}$ & $\begin{array}{l}\text { The main accents in the evolution of social } \\
\text { relations mean the formation of mechanisms of } \\
\text { artificial coercion to change the way of life, the } \\
\text { habitat of socio-cultural and institutional forms } \\
\text { in order to create the consumer sphere, which: } \\
\text { 1) merges eclectic consumer demands into } \\
\text { sustainable "consumer flows". } \\
\text { 2) ensures the extension of the life cycle of } \\
\text { obsolete products, } \\
\text { For example, using forms such as: } \\
\text { - globalization of the sphere of consumption based } \\
\text { on consumption standards, } \\
\text { - lifestyle stylization, } \\
\text { - support of the trend structure of consumption } \\
\text { processes }\end{array}$ \\
\hline
\end{tabular}

Figure 1. The focus of the evolution of public relations in technogenic globalization. Source: developed by the author. 
Summing up the emerging problems, it should be said that in a period of high maturity, the impact of technogenic globalization on the organization of society in terms of the integral vector of social transformations is meaningfully manifested in the following:

a) in the general deceleration of the speed and depth of the technogenesis process; b) in the growing share of imbalances in the structural and functional organization of practically all spheres of society, associated with technogenesis;

c) in imbalances at the level of social relations (economic, institutional, cultural/moral, etc.).

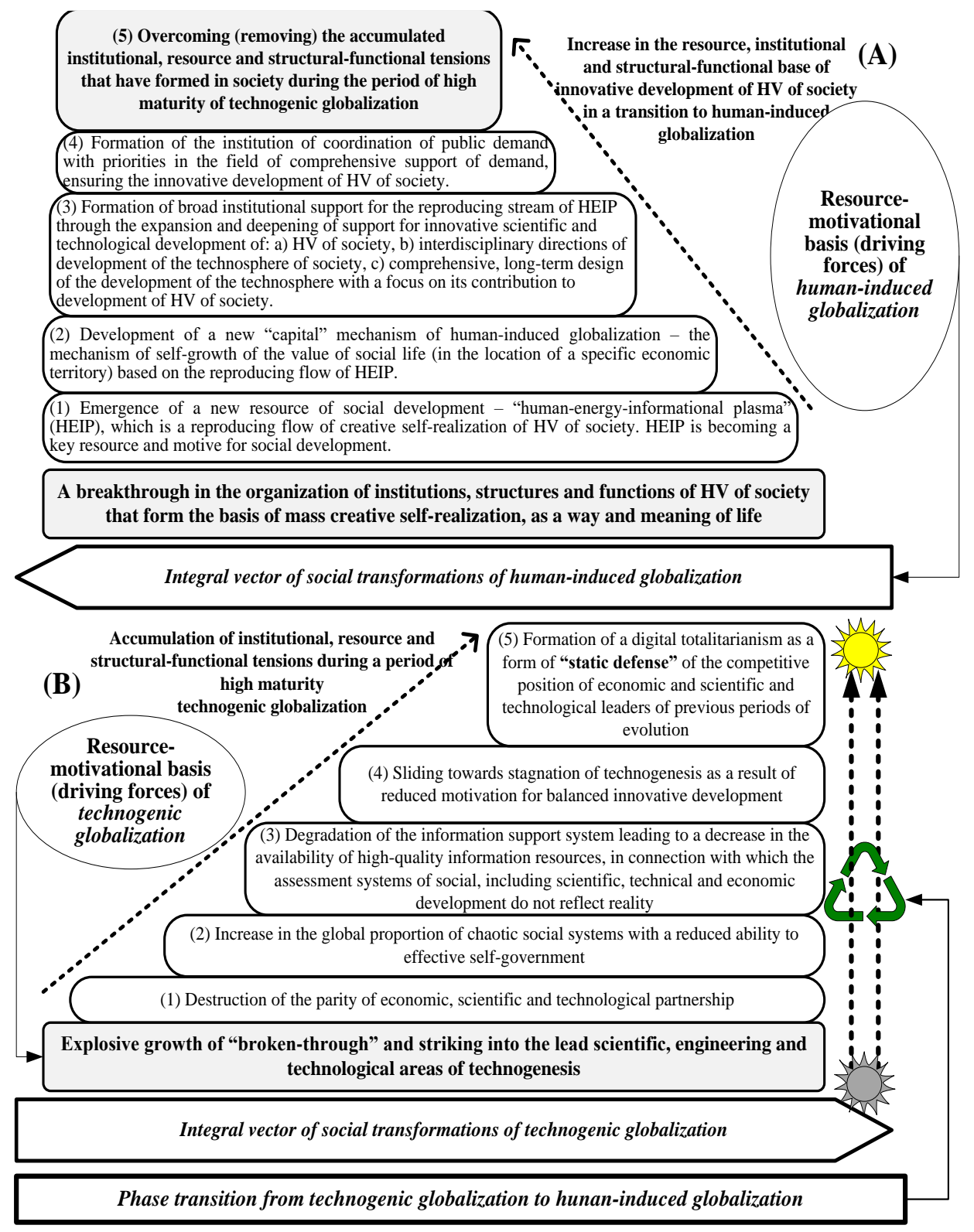

Figure 2. Model of a phase transition from technogenic globalization to human-induced globalization. Source: developed by the author.

In accordance with the systemic paradigm considering technogenic globalization, this is a consequence of the total dominance in the threeelement system of the mechanism of technogenic globalization of the technosphere. This inhibits the development of other elements as especially clearly manifested in the HV of society falling behinnd. Moreover, $\mathrm{HV}$ of society suffers especially strongly, since it finds itself in a service position in relation to both the 


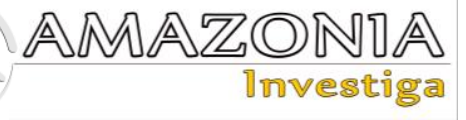

technosphere and to the structures and institutions oriented towards it. As a result of such pressure by both elements, HV of society falls into a converging corridor of development, which determines the limit of the development of technogenic globalization (Figure 3).

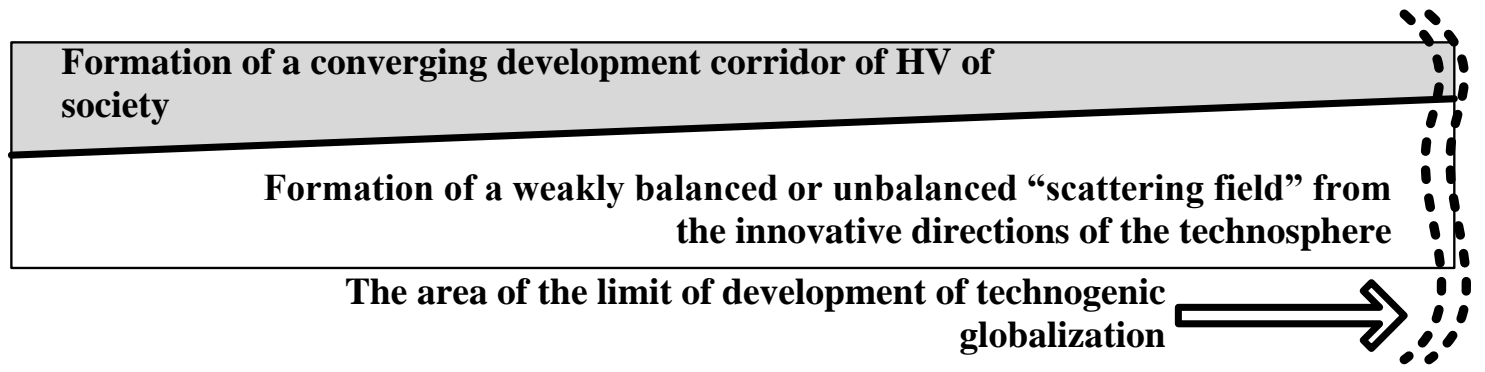

Figure 3. Scheme of corridors for the development of HV of society and the technosphere at the stage of technogenic globalization.

Source: developed by the author.

In the systemic paradigm, reaching the limit of technogenic globalization is the achievement of the quality and speed of organizational processes which cause the following:

a) the natural entropy of institutional and organizational structures is as close as possible to the synergy from technogenic globalization;

b) the costs of integration as a result of globalization are not compensated by the development of integrated systems.

The limit for the development of technogenic globalization can be fixed by the following markers of the resource-motivational deficit of scientific, technological and innovative development, which gradually form a total deficiency of social development (Figure 4):

1) a deficiency of resources for the scientific and technological development of the manufacturing sector (occurs as a result of the unbalanced development of the technosphere);
2) lack of motivation for scientific and technological development in HV of society as a whole;

3) a low share of the involvement of HV of society in the spheres of activity that form a qualitative base of breakthrough innovations (research, development, engineering support for innovative development) with a simultaneous bias towards the involvement of $\mathrm{HV}$ of society in the activities that force their development using already implemented innovations;

4) lack of clear, long-term demand for hightech innovative development from the real sector of the economy, and state and institutional support of society;

5) massive obsolescence of the structures and functions in HV of society, which provokes massive falsifications of the quality of $\mathrm{HV}$ of society at all levels and in all areas;

6) social opportunism in two main forms: in the form of "fatigue" from progress: social apathy, downshifting, etc., and in the form of considering technogenesis by the subjects of $\mathrm{HV}$ of society as an end in itself. 
Integral vector of social transformations at the stage of technogenic globalization of society, accumulating structural, functional and institutional tensions in society

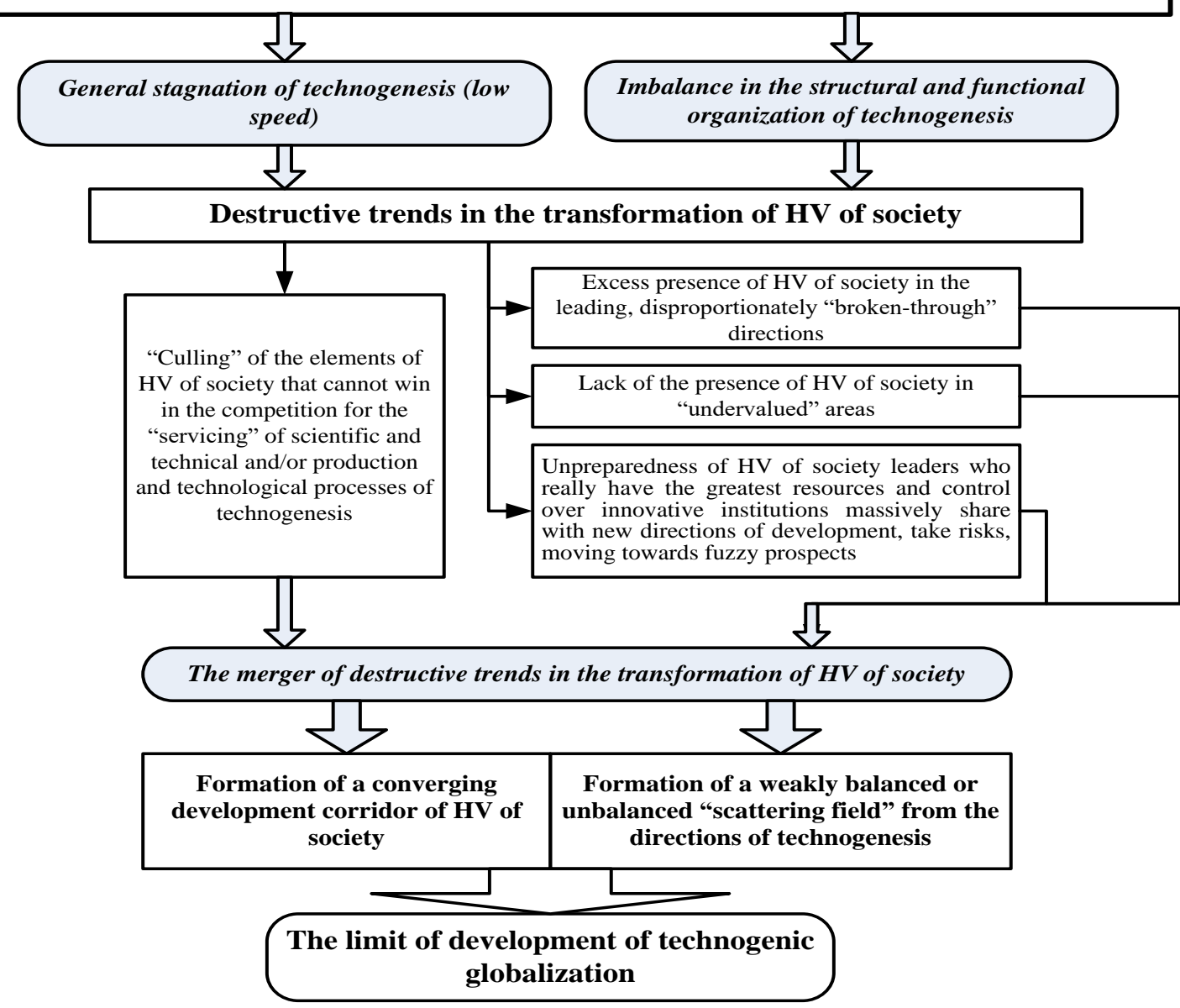

Figure 4. Structural and logical diagram of substantiation of the limit of achieving technogenic globalization in a period of high maturity.

Source: developed by the author.

It should be noted here that markers of a simultaneous total deficiency of social development are characteristic for:

1) the current state of the global institutional and economic organization, markers manifest themselves especially clearly in the countries of the developed West (Ehrlich \& Ehrlich, 2013; Taylor, 2020);

2) the state of the late USSR and the period of its collapse (Sakwa, 2013; Inglehart \& Welzel, 2009).

This is an important remark, since it allows making a hypothetical assumption about the universality of the laws of technogenesis in the process of a transition to an information society, at least in terms of a transition from the stage of technogenic globalization to the stage of humaninduced globalization.
Reaching the limit of development of technogenic globalization determines a transition to the second stage of globalization - humaninduced, which marks the actual transition to an information society. This transition is realized through a phase transition of the social system (Figures 2 (part A), 3). This is precisely a phase transition, since: 1) globalization, as an integrative social mechanism for ensuring a transition to an information society, remains, but the integral vector of social transformations of the vector of technogenic globalization changes to the vector of human-induced globalization; 2) the elemental composition of globalization as a mechanism is preserved, but the ranks of the system change - with human-induced globalization, HV of society becomes the leader. 


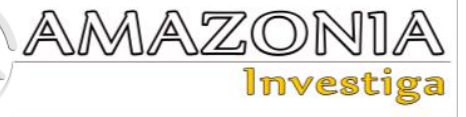

Conclusions

As the author has shown above, institutional and structural-functional problems are growing when approaching the limit of technogenic globalization, and this determines the lack of alternatives to a transition to human-induced globalization. With the successful passage of a phase transition to human-induced globalization, one should expect a decrease in the institutional, resource and structural-functional problems accumulated by society during the period of high maturity of technogenic globalization (Figure 2a). But for this, the main vector of the development of society at the stage of humaninduced globalization should be focused on human genesis, based on technogenesis. That is, it is such a human genesis that uses the process of technogenesis as:

a) a method of training (developing the scientific and production basis of engineering and technology, developing the formed scientific and technological areas, an individual develops himself/herself);

b) a means (material) that supports the processes of human genesis (for example, a means of improving the environment, optimizing the living environment, physiological, mental, psychological improvement).

All this determines the place and role of the technosphere, and its most important institution - artificial intelligence.

\section{Bibliographic references}

Ahlqvist, T. (2005). From information society to biosociety? On societal waves, developing key technologies, and new professions. Technological Forecasting and Social Change, 72(5), 501-519. https://doi.org/10.1016/j.techfore.2004.06.00 1

Banuls, V.A., \& Salmeron, J.L. (2007). Benchmarking the information society in the long range. Futures, 39(1), 83-95. https://doi.org/10.1016/jfutures.2006.03.006

Batukova, L., Bagdasaryan, N., Belyakova, G., Vladimirova, O., \& Belyakov, S. (2019b). The Model of Innovation Development Metasystem. Quality-Access to Success, 20(172),

19-24. https://www.calitatea.ro/assets/arhiva/2019/ QAS_Vol.20_No.172_Oct.2019.pdf

Batukova, L.R., Bezrukikh, D.V., Senashov, S.I., Levshina, V.V., \& Yevseeva, S.A. (2019a). Modernization and innovation: Economic and institutional role. Espacios, 40 (11), article №

3. https://www.revistaespacios.com/a19v40n11 /19401103.html

Drotianko, L., \& Yahodzinskyi, S. (2019). V. Vernadsky: from the geochemistry of technogenesis to the scientific thought of the global society. E3S Web of Conferences, 135, article № 03079. https://doi.org/10.1051/e3sconf/2019135030 79

Ehrlich, P. R., \& Ehrlich, A. H. (2013). Can a collapse of global civilization be avoided? Proceedings. Biological sciences, 280(1754), 20122845. https://doi.org/10.1098/rspb.2012.2845

Inglehart, R., \& Welzel, C. (2009). How development leads to democracy: what we know about modernization. Foreign Affairs, $88(2)$, 33-48. https://www.jstor.org/stable/20699492

Kamann, D.J.F., \& Nijkamp, P. (1991). Technogenesis: Origins and diffusion in a turbulent environment. Technological Forecasting and Social Change, 39 (1-2), 45-66. https://doi.org/10.1016/00401625(91)90028-E

Keskinen, A. (2001). Future democracy in the information society. Futures, 33 (3-4), 339-346. https://doi.org/10.1016/S00163287(00)00075-6

Kumar, A., \& Kalse, A. (2021). Usage and adoption of artificial intelligence in SMEs. Materials Today: Proceedings, in Press, https://doi.org/10.1016/j.matpr.2021.01.595

Martin, W.J. (1997). The global information society. Hampshire: Aslib Gower. https://www.routledge.com/The-GlobalInformationSociety/Martin/p/book/9780566078125

Nusratullin, I., Yeremeeva, O., Butorina, G., Novikov, S., \& Kovazhenkov, M. (2020). The main provisions of the evolutionary doctrine in economics. Amazonia Investiga, 9(25), 230-241. https://amazoniainvestiga.info/index.php/am azonia/article/view/1062

O'Neill, B. (2012). Trust in the information society. Computer Law \& Security Review, 28(5), 551-559. https://doi.org/10.1016/j.clsr.2012.07.005

Sakwa, R. (2013). The Soviet collapse: Contradictions and neo-modernisation. Journal of Eurasian Studies, 4(1), 65-77. https://doi.org/10.1016/j.euras.2012.07.003

Taylor, K.B. (2020). The passing of western civilization. Futures, 122, article № 102582. https://doi.org/10.1016/j.futures.2020.10258 2 
Tsoukas, H. (1997). The tyranny of light: The temptations and the paradoxes of the information society. Futures, 29 (9), 827-843. https://doi.org/10.1016/S00163287(97)00035-9

Tsuji, M. (2019). Envisioning a new society transformed by ICTs: The post-information society. Telecommunications Policy, 43(9), article №101871. https://doi.org/10.1016/j.telpol.2019.101871

Verma, S., Sharma, R., Deb, S., \& Maitra, D. (2021). Artificial intelligence in marketing: Systematic review and future research direction. International Journal of
Information Management Data Insights, 1(1), article № 100002 . https://doi.org/10.1016/j.jjimei.2020.100002

Xu, J.J., \& Babaian, T. (2021). Artificial intelligence in business curriculum: The pedagogy and learning outcomes. The International Journal of Management Education, 19(3), article № 100550. https://doi.org/10.1016/j.ijme.2021.100550

Zhang, C., \& Lu, Y. (2021). Study on artificial intelligence: The state of the art and future prospects. Journal of Industrial Information Integration, 23, article № 100224 . https://doi.org/10.1016/j.jii.2021.100224 